\title{
Disposal and utilization of broiler slaughter waste by composting
}

\author{
N Bharathy, R Sakthivadivu, K Sivakumar, V Ramesh Saravanakumar \\ Veterinary College and Research Institute \\ Namakkal, Tamil Nadu, India \\ Corresponding author: N Bharathy, email: Ipmbharathi@gmail.com \\ Received: 20-11-2011, Accepted: 05-12-2011, Published Online: 10-03-2012 \\ doi: $10.5455 /$ vetworld.2012.359-361
}

\begin{abstract}
Aim: To know the feasibility of hygienic and environmentally safe method of disposal of broiler slaughter house waste with coir pith and caged layer manure.

Materials and Methods: Compost bins ( 4 feet $\mathrm{x} 4$ feet $\mathrm{x} 4$ feet) were established with concrete blocks with air holes to facilitate aerobic composting. The broiler slaughter waste and coconut coir pith waste were collected from the local market, free of cost. The caged layer manure available from poultry farms were utilized as manure substrate. Physical properties and chemical composition of ingredients were analyzed and a suitable compost recipe was formulated (USDA-NRCS, 2000). Two control bins were maintained simultaneously, using caged layer manure with coir pith waste and water in a ratio of 0.8:3:1.2 $\left(\mathrm{T}_{2}\right)$ and another one bin using caged layer manure alone $\left(\mathrm{T}_{3}\right)$.

Results: At the end of composting, moisture content, weight and the Volume of the compost were reduced significantly $(\mathrm{P}<0.01), \mathrm{pH}, \mathrm{EC}, \mathrm{TDS}$, total organic carbon and total nitrogen content were also significantly $(\mathrm{P}<0.01)$ reduced at the finishing of composting. Calcium, phosphorous and potassium content was progressively increased during composting period. The finished compost contains undetectable level of salmonella. Cowpea and sorghum seeds showed positive germination percentage when this finished compost was used. It indicated that all of the finished compost was free from phytotoxin substances.

Conclusion: The results indicated that, composting of slaughter waste combined with coir pith waste may be a hygienic and environmentally safe method of disposal of broiler slaughter house waste.

Keywords: Composting, Disposal, Nutrient content, Slaughter waste
\end{abstract}

To cite this article :

Bharathy N, Sakthivadivu R, Sivakumar K, Ramesh Saravanakumar V (2012) Disposal and Utilization of Broiler Slaughter waste by Composting, Vet World 5(6):359-361, doi: 10.5455/vetworld.2012.359-361

\section{Introduction}

Poultry broiler meat industry is growing tremendously. Presently broiler birds are slaughtered by small and medium sized retailers and the waste like feathers, inedible offal and undigested feed materials generated from the slaughter is a problem for the operators for handling and disposing. Normally such wastes are unutilized and thrown out along with municipal solid waste, which attracts stray animals and wild birds, thus creates bio-security problems. Further, during decomposition, such waste creates fly and odour problem also.

Composting is a natural process by which the beneficial microorganisms decompose the organic waste quickly and generate heat which helps to eliminate pathogens. Coir pith waste is available in plenty from coir industry which can act as a good carbon source.

Hence this work is proposed to know the feasibility of hygienic and environmentally safe method of disposal of broiler slaughter house waste with coir pith and caged layer manure.

\section{Materials and Methods}

Compost bins ( 4 feet $\mathrm{x} 4$ feet $\mathrm{x} 4$ feet) were established with concrete blocks with air holes to facilitate aerobic composting. The broiler slaughter waste and coconut coir pith waste were collected from the local market on free of cost. The caged layer manure available from poultry farms were utilized as manure substrate.

Physical properties and chemical composition of ingredients were analyzed and a suitable compost recipe was formulated [1]. While formulating compost recipe the $\mathrm{C}: \mathrm{N}$ ratio and moisture level was fixed as 20:1 and 60 per cent, respectively. A base layer of 6 inches of caged layer manure was spread after which the bins were filled by sequential layering of slaughter waste, manure substrate, coir pith waste and water in a ratio of 1:3:1.4:1.9 $\left(\mathrm{T}_{1}\right)$. Composting process was carried 
Disposal and Utilization of Broiler Slaughter waste by Composting

Table-1. Means \pm SE of chemical properties of slaughter waste compost

\begin{tabular}{|c|c|c|c|c|c|c|c|c|}
\hline \multirow[t]{2}{*}{ Chemical properties } & \multicolumn{4}{|c|}{ Primary stage } & \multicolumn{4}{|c|}{ Secondary stage } \\
\hline & T1 & T2 & T3 & 'F' value & T1 & T2 & T3 & 'F' value \\
\hline $\begin{array}{l}\text { Peak temperature }\left({ }^{\circ} \mathrm{C}\right) \\
\text { Persistency of thermophilic } \\
\text { (above } 55^{\circ} \mathrm{C} \text { ) temperature }\end{array}$ & $\begin{array}{c}55.63 \pm 0.24 \\
6.00 \pm 0.00\end{array}$ & $\begin{array}{c}43.60 \pm 1.79 \\
0.00\end{array}$ & $\begin{array}{l}55.15 \pm 1.79 \\
2.00 \pm 1.00\end{array}$ & - & $\begin{array}{c}56.00 \pm 0.66 \\
3.00 \pm 0.00\end{array}$ & $\begin{array}{c}40.23 \pm 2.81 \\
0.00\end{array}$ & $\begin{array}{l}55.25 \pm 0.25 \\
2.00 \pm 1.00\end{array}$ & - \\
\hline $\begin{array}{l}\text { Total composting period (days) } \\
\text { Moisture } \% \text { ) }\end{array}$ & $\begin{array}{l}39.00 \pm 0.00 \\
34.78 \pm 2.50\end{array}$ & $\begin{array}{l}8.50 \pm 1.00 \\
31.49 \pm 1.20\end{array}$ & $\begin{array}{l}19.00 \pm 0.00 \\
26.09 \pm 1.22\end{array}$ & - & $\begin{array}{l}13.00 \pm 0.00 \\
29.56 \pm 1.61\end{array}$ & $\begin{array}{c}6.00 \pm 0.00 \\
32.04 \pm 1.68\end{array}$ & $\begin{array}{l}14.00 \pm 0.00 \\
23.44 \pm 0.30\end{array}$ & - \\
\hline Weight reduction (\%) & $\begin{array}{c}34.10 \pm 2.00 \\
-\end{array}$ & $\begin{array}{c}31.49 \pm 1.20 \\
-\end{array}$ & $\begin{array}{c}20.09 \pm 1.22 \\
-\end{array}$ & - & $45.35 \pm 0.31$ & $30.02 \pm 2.61$ & $23.60 \pm 0.00$ & ** \\
\hline Volume reduction (\%) & - & - & - & - & $18.78 \pm 0.59$ & $10.17 \pm 1.12$ & $22.91 \pm 0.00$ & ** \\
\hline Total dissolved salts (ppt) & $2.07 \pm 0.05$ & $2.64 \pm 0.18$ & $2.70 \pm 0.10$ & $* *$ & $2.73 \pm 0.12$ & $1.40 \pm 0.08$ & $1.55 \pm 0.12$ & ** \\
\hline Total ash (\%) & $65.35 \pm 2.43$ & $66.21 \pm 1.43$ & $60.95 \pm 1.29$ & NS & $67.45 \pm 2.39$ & $68.95 \pm 0.85$ & $68.82 \pm 1.09$ & NS \\
\hline Total carbon (\%) & $20.09 \pm 1.41$ & $19.59 \pm 0.83$ & $17.25 \pm 1.96$ & NS & $18.87 \pm 1.38$ & $18.01 \pm 0.49$ & $18.80 \pm 0.63$ & $* *$ \\
\hline Total nitrogen $(\mathrm{g} / \mathrm{kg})$ & $13.20 \pm 0.84$ & $11.59 \pm 0.42$ & $15.99 \pm 0.44$ & $* \star$ & $10.34 \pm 0.42$ & $12.65 \pm 0.45$ & $10.68 \pm 0.52$ & * \\
\hline C:N ratio & $16.13 \pm 1.64$ & $17.32 \pm 1.22$ & $10.83 \pm 1.13$ & ** & $18.91 \pm 1.91$ & $14.36 \pm 0.48$ & $17.37 \pm 0.99$ & NS \\
\hline Calcium $(\mathrm{g} / \mathrm{Kg})$ & $30.10 \pm 3.73$ & $36.97 \pm 0.85$ & $41.11 \pm 1.05$ & ** & $65.37 \pm 1.28$ & $51.37 \pm 1.28$ & $74.49 \pm 1.14$ & * \\
\hline Phosphorous $(\mathrm{g} / \mathrm{Kg})$ & $29.45 \pm 1.72$ & $20.58 \pm 1.38$ & $32.49 \pm 0.81$ & ** & $39.44 \pm 2.97$ & $19.00 \pm 0.93$ & $17.80 \pm 0.89$ & ** \\
\hline Potassium ( $/ \mathrm{g} / \mathrm{Kg})$ & $25.27 \pm 0.54$ & $30.60 \pm 0.85$ & $31.66 \pm 0.48$ & ** & $36.13 \pm 1.80$ & $33.07 \pm 1.42$ & $29.95 \pm 1.62$ & * \\
\hline
\end{tabular}

** Significant at one per cent level $\mathrm{P}<0.01, *$ Significant at five per cent level $\mathrm{P}<0.05$, NS Non significant

out as per the procedure followed by USDA-NRCS [1] and Sivakumar et al [2].

Two control bins were maintained simultaneously, using caged layer manure with coir pith waste and water in a ratio of 0.8:3:1.2 $\left(\mathrm{T}_{2}\right)$ and another one bin using caged layer manure alone $\left(\mathrm{T}_{3}\right)$. The physical properties and chemical composition of finished compost materials were analyzed and evaluated for the microbial load [3].

Physicochemical Analysis: Compost samples were collected at the end of secondary stage. Samples were gathered from different locations to get a representative sample. Sample ( $250 \mathrm{~g})$ was collected from six different locations and stored in an air tight polythene bag and transferred immediately for moisture estimation. Moisture content of composting samples was determined by drying at $105^{\circ} \mathrm{C}$ in the hot air oven for 24 hours. Electrical conductivity (EC) and $\mathrm{pH}$ were measured using digital $\mathrm{pH}$ meter (Water proof $\mathrm{pH}$, EC/TDS and Temperature meter, HANNA Instruments, USA, model No. HI 98130) by preparing 1: $10 \mathrm{w} / \mathrm{v}$ compost - water extract. Total organic matter (TOM) was calculated by gravimetric loss on ignition produced by ashing the samples in a muffle furnace for 24 hours at $430^{\circ} \mathrm{C}$. The total organic carbon content was calculated from the ash content using the formula Total organic carbon $=[1$-ash content $\mathrm{x}(1000)]$. The total carbon was calculated from total organic matter value using the conventional "Van Bemelem Factor" of 1.724. The weight loss on ignition was divided by 1.724 to give the percentage of total carbon. Compost samples were analysed for total Kjeldahl nitrogen, phosphorus and calcium. The concentration of potassium was analyzed using Flame photometer as described by Jackson. The data thus collected were statistically analyzed by two way analysis with replicate as per the methods suggested by Snedecor and Cochran [4].

\section{Results and Discussion}

The composting process was done in two stages. Immediately after filling up of compost bins, the temperature, increased from third day onwards and reached the peak temperature of $55.63{ }^{\circ} \mathrm{C}$ in $\mathrm{T}_{1}$ followed by $55.15^{\circ} \mathrm{C}_{\text {in }} \mathrm{T}_{3}$ and $\mathrm{T}_{2}$ recorded least $\left(43.60^{\circ} \mathrm{C}\right)$ in the primary stage and similar trend was noticed in the secondary stage also. Temperature above $55^{\circ} \mathrm{C}$ for three cumulative days is sufficient to eliminate maximum pathogens [3, 5]. In this work broiler slaughter house waste compost recorded persistency of thermophilic temperature for six days which ensures bio-safety of composting process.

Slaughter house waste took 52 days (both primary and secondary stage) to finish the composting process which are comparable with the results of Sivakumar et al. [2] and Sakthivadivu [6]. At the end of composting, moisture content, weight and volume of the compost was reduced significantly $(\mathrm{P}<0.01)$, $\mathrm{pH}, \mathrm{EC}, \mathrm{TDS}$, total organic carbon and total nitrogen content were also significantly $(\mathrm{P}<0.01)$ reduced at the finishing of composting (Table 1).

Calcium, phosphorous and potassium content was progressively increased during composting period (Table-1). At the end of composting total bacterial count and coliform was reduced. This reduction was mainly due to increasing temperature [3]. The finished compost contains undetectable level of salmonella [7,8].

Cowpea and sorghum seeds showed good germination percentage when this finished compost 
was used $[9,10]$. It indicated that all the finished compost were free from phytotoxin substances. The results indicated that, composting of slaughter waste combined with coir pith waste will be a hygienic and environmentally safe method of disposal of broiler slaughter house waste.

\section{Conclusion}

The results indicated that, composting of slaughter waste combined with coir pith waste may be a hygienic and environmentally safe method of disposal of broiler slaughter house waste.

\section{Acknowledgements}

The authors wish to thanks the Dean, Veterinary College and Research Institute, Namakkal and Tamil Nadu State Council for Science and Technology, Government of Tamil Nadu, Chennai for the financial assistance.

\section{Competing interests}

The authors declare that they have no competing interests.

\section{References}

1. USDA-NRCS. (2000): United States Department of Agriculture - Natural Resources Conservation Service. Composting : Environmental Engineering National Engineering Handbook, 637.
2. Sivakumar, K., Ramesh Saravana Kumar, V., Richard Jagatheesan, P.N., Viswanathan, K., and Chandrasekaran, D (2008a): Bioresour. Technol., 99 : 3708.

3. Sivakumar, K., Ramesh Saravana Kumar, V., Richard Jagatheesan, P.N., Viswanathan, K., and Chandrasekaran, D (2008b): Indian Vet. J., $85: 526$.

4. Snedecor, G.W. and W.G. Cochran, 1989. Statistical Methods. 8th Edition, Iowa State Press, Ames, Iowa, USA., pp: 254-268.

5. Hang, R.T. (1993). The practical handbook of compost engineering. Lewis Publishers Press, Inc Boca Raton, Florida.

6. Sakthivadivu, R. (2008): Composting of poultry waste using low cost carbonaceous M.V.Sc., materials. Thesis, Tamil Nadu Veterinary and Animal sciences University, Chennai-600 051.

7. Tiquia, S.M., N.F.Y. Tam and I.J. Hodgkiss, (1998b). Salmonella elimination during composting of spent pig litter. Bioresour. Technol., 63: 193-196.

8. Lung, A.J., C.M. Lin, J.M. Kim, M.R. Marshall, R. Hordstedt, N.P. Thompson and C.I. Wei, (2001). Destruction of Escherichia coli 0157:H7 and salmonella enteridis in cow manure composting. Journal of Food protection, 64(9): 1309- 1314.

9. Zucconi, F., A. Pera, M. Forte and M. de Bertoldi, 1981. Evaluating toxicity in immature compost. Biocycle, $22: 54-57$.

10. Sivakumar, K. (2006). Disposal and utilization of poultry carcass by aerobic composting. $\mathrm{Ph}$. D.,thesis submitted to Tamil Nadu Veterinary and Animal Sciences University. Chennai. India. 